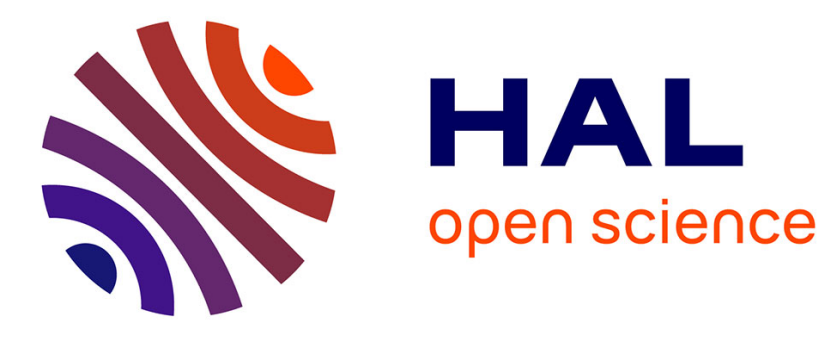

\title{
Impacts of ocean acidification in a warming Mediterranean Sea: An overview
}

Thomas Lacoue-Labarthe, Paulo A.L.D. Nunes, Patrizia Ziveri, Mine Cinar, Frédéric Gazeau, Jason M. Hall-Spencer, Nathalie Hilmi, Paula Moschella, Alain Safa, Didier Sauzade, et al.

\section{To cite this version:}

Thomas Lacoue-Labarthe, Paulo A.L.D. Nunes, Patrizia Ziveri, Mine Cinar, Frédéric Gazeau, et al.. Impacts of ocean acidification in a warming Mediterranean Sea: An overview. Regional Studies in Marine Science, 2016, 10.1016/j.rsma.2015.12.005 . hal-01253944

\section{HAL Id: hal-01253944 https://hal.science/hal-01253944}

Submitted on 11 Jan 2016

HAL is a multi-disciplinary open access archive for the deposit and dissemination of scientific research documents, whether they are published or not. The documents may come from teaching and research institutions in France or abroad, or from public or private research centers.
L'archive ouverte pluridisciplinaire $\mathbf{H A L}$, est destinée au dépôt et à la diffusion de documents scientifiques de niveau recherche, publiés ou non, émanant des établissements d'enseignement et de recherche français ou étrangers, des laboratoires publics ou privés. 


\section{Impacts of ocean acidification in a warming Mediterranean Sea: anoverview}

Thomas Lacoue-Labarthe ${ }^{1,2,{ }^{*} \dagger}$, Paulo A.L.D. Nunes ${ }^{3,4, *}$, Patrizia Ziveri ${ }^{5,6}$, Mine Cinar ${ }^{7}$, Frédéric Gazeau $^{8,9}$, Jason M. Hall-Spencer ${ }^{10}$, Nathalie Hilmi ${ }^{1,11}$, Paula Moschella ${ }^{12}$, Alain Safa $^{13}$, Didier Sauzade $^{14}$, Carol Turley ${ }^{15}$

\footnotetext{
${ }^{1}$ International Atomic Energy Agency - Environment Laboratories, 4 Quai Antoine Ier, Monaco

${ }^{2}$ Littoral Environnement et Sociétés (LIENSs), UMR 7266 CNRS-Université de La Rochelle, Institut du Littoral et Environnement, 2 rue Olympe de Gouges, 17000 La Rochelle, France

${ }^{3}$ Policy and Technical Experts Committee, WAVES - Wealth Accounting and Valuation of Ecosystem Services, Environmental Economics and Indicators Unit, World Bank

${ }^{4}$ Institut de Ciències del Mar, CSIC, Psg. Marítim de la Barceloneta 37-49, Barcelona, Spain

${ }^{5}$ Institute of EnvironmentalScience and Technology, UniversitatAutonomòma de Barcelona (UAB)

Carretera de les Columnes, S/N, Edifici Z Campus de la UAB, 08193 Bellaterra, Barcelona · Spain

${ }^{6}$ Institució Catalana de Recerca i EstudisAvançats (ICREA), Barcelona, Catalonia, Spain

${ }^{7}$ QuinlanSchool of Business, Loyola University Chicago, Chicago, Illinois 60611, USA

${ }^{8}$ Laboratoire d'Océanographie de Villefranche, CNRS-INSU, BP 28, 06234 Villefranche-sur-Mer Cedex, France

${ }^{9}$ Sorbonne Universités, UPMC Univ Paris 06, Observatoire Océanologique de Villefranche, 06230, Villefranchesur-Mer Cedex, France

${ }^{10}$ Marine Institute, Plymouth University, Plymouth PL4 8AA, United Kingdom.

${ }^{11}$ Centre Scientifique de Monaco, Avenue Saint-Martin, 98000 Monaco, Principality of Monaco

12 The Mediterranean Science Commission, CIESM, Monaco, Principality of Monaco

${ }^{13}$ Skill Partners, Nice, France

${ }^{14}$ Plan Bleu, Villa Valmer, 271 Corniche Kennedy, 13007 Marseille, France

${ }^{15}$ Plymouth Marine Laboratory, Prospect Place, The Hoe, Plymouth PL1 3DH, UK
}

\footnotetext{
* Both authors contributed equally to this work.

† Correspondingauthor:UMR 7266 CNRS-Université de La Rochelle, Institut du Littoral et Environnement, 2 rue Olympe de Gouges, 17000 La Rochelle, France, +33 54645 83 88, tlacouel@univ-lr.fr
} 


\section{Abstract}

Mediterranean Sea fisheries supply significant local and international markets, based largely on small pelagic fish, artisanal fisheries and aquaculture of finfish (mainly seabass and seabream) and shellfish (mussels and oysters).Fisheries and aquaculturecontribute to the economy of countries bordering this sea and provide food and employment to coastal communitiesemploying $c a 600,000$ people.Increasing temperatures and heat wave frequency are causing stress and mortality in marine organismsand ocean acidification is expected to worsen these effects, especially for bivalves and coralligenous systems. Recruitment and seed production present possible bottlenecks for shellfish aquaculture in the future since early life stages are vulnerable to acidification and warming. Although adult finfish seem able to withstand the projected increases in seawater $\mathrm{CO}_{2}$, degradation of seabed habitats and increases in harmful blooms of algae and jellyfish might adversely affect fish stocks. Ocean acidification should therefore be factored into fisheries and aquaculture management plans. Rising $\mathrm{CO}_{2}$ levels are expected to reduce coastalbiodiversity,altering ecosystem functioning and possibly impactingtourism being theMediterranean the world's most visited region.Werecommendthat ocean acidification is monitored in key areas of the Mediterranean Sea, with regular assessments of the likely socio-economic impacts to build adaptive strategies for the Mediterranean countries concerned.

Keyword: Mediterranean, climate change, warming, acidification, ecosystemservices, fisheries, habitat loss,ecosystemvulnerability. 


\section{Introduction}

The Mediterranean Sea has a restricted exchange of seawater with the Atlantic Ocean via the Strait of Gibraltar in the West and the Black Sea in the East and to a lesser extent with the Red Sea via the Suez Canal (Fig. 1). The region supports cold, temperate and subtropical biota and is a so called 'biodiversity hotspot' with $7 \%$ of the world's known species living in $0.82 \%$ of the ocean area[1]. This exceptional biodiversitybenefits economic sectorssuch as tourism andcultural heritage. In addition, aquaculture and fisheries contribute to local and national income going back to thousands of years. Human-induced $\mathrm{CO}_{2}$ emissionis a global phenomenawith different regional consequences. The Mediterranean Sea is affected in several ways through climate change and ocean acidification.Mediterraneanacidification is already detectable [2,3] and combined with the rapid warming, the increase frequency of extreme weather events and the rapid increase of human population around its coasts have serious consequences for the region.

\section{Mediterranean fisheries and aquaculture}

Fisheries and aquaculture in the Mediterranean Sea represent 1\% of world landings, and 2\% in terms of economic value. While fishcatches have remained quite stable since the 1990's, aquaculture hasquadrupled in production reaching 20\% of production in 2011 (Fig. 2). While aquaculture production is mainly supported by northern European countries, the fishery sector mainly comprises artisanal activities ( $~ 80 \%$ of the flotilla; [4]), being more common in southern Mediterranean countries.

\section{Capture fishery}

Pelagic fish account for $53 \%$ of the total Mediterranean catch (Fig. 3; about 460,000 tonnesin 2011) with landings dominated by sardine (Sardinapilchardus) and anchovy 
(Engraulisencrasicolus) (Fig. 4).

Demersal fish make up $30 \%$ of landings,crustaceans $7 \%$ and molluscs(including cephalopods) comprise $10 \%$ of Mediterranean landings. The striped venus clam,Chameleagallina (around 20,000 tonnes $\mathrm{yr}^{-1}$ ) is mainly harvested in the Adriatic Sea and constitutes $70 \%$ of molluscs landings. Small-scale fisheries dominate $(>60 \%)$ the fishing sector in the Mediterranean Sea.Capture fisheries and aquaculture in the Mediterranean Sea provide a central source of food and employment: they directly employ 250,000 and 123,000 in fisheries and aquaculture, respectively and employ about 210,000 people for secondary sector [4]. In this context, it is of foremost importance to assess the impacts of ocean acidification on these two economic sectors.

\section{Aquaculture}

Fish and mollusc production dominates Mediterranean aquaculture although crustaceans are also farmed. The production of gilthead seabream (Sparusaurata) has risen rapidly from 3,833 tonnes in 1990 to 143,295 tonnes in 2010 (worth approximately US\$ 785 million). European seabass (Dicentrarchuslabrax) production rose from 2,944 t in 1990 to $131,509 \mathrm{t}$ in 2010 (valued at US\$ 786 million). In 2010, the main producers of gilthead seabream were Greece (43\%), Turkey (20\%) and Spain (13\%), whereas the top three producers of European seabasswere Turkey (40\%), Greece (28\%) and Egypt (12\%). In 2010, $81 \%$ of the total Mediterraneanmeagre (Argyrosomusregius) production was in Egypt [5].

The oyster Ostreaedulishas been farmed in the Mediterranean since the 1st century BC. But in the 1970s these oysters suffered mass mortalities due to pathogenic protozoans and have been progressively replaced in aquaculture by the Pacific oyster (Crassostrea gigas), as it is 
more resistant. Mediterranean bivalve yields increased greatly between the 1950's and the 1990's and have now stabilizedat around 180,000 t $\mathrm{y}^{-1}$ (Fig. 5).Italy produces $67 \%$ of the Mediterranean bivalve production, followed by Greece and France (Fig. 5). This production is dominated by the Mediterranean mussel (Mytilusgalloprovincialis), which represents almost three quarters of the total Mediterranean shellfish production $\left(120,000 \mathrm{t} \mathrm{y}^{-1}\right.$; Fig. 5 C). Japanese carpet shell (Ruditapesphilippinarum; about 35,673 tonnes $\mathrm{yr}^{-1}$ with around $98 \%$ in Italy) and the Pacific cupped oyster are the other important cultivated species $(8,000$ $\mathrm{t}^{-1}$ and $300 \mathrm{t} \mathrm{yr}^{-1}$ by Spain and France).

\section{Human impacts}

Multiple global, regional and local driversare occurring in the Mediterranean Sea and these can have synergistic impacts [6]. These driversinclude warming, invasive species, habitat loss, overfishing and pollution [4,7-10] and are already challenging marine organisms, ecosystems and the ecosystem goods and services that these seas are providing to human societies.

\section{Ocean warming}

The mean maximum summer seawater temperature of the Mediterranean Sea has risen by around $1{ }^{\circ} \mathrm{C}$ during the last three decades [11] and there has been an increase in the frequency and intensity of marine heat waves[12]. Seawater warming can kill organisms such as the mussel Mytilusgalloprovincialis[13,14] during summer and autumn periods when seawater temperature is above $26-27{ }^{\circ} \mathrm{C}$. Shellfish farmers are being forced to sell their product earlier than they would otherwise wish to avoid harvesting loss mass mortalities during warm-water events[15].

Continued warming is likely to cause mass mortalities of the endemic seagrassPosidoniaoceanica([16]), invertebrates [12], including habitat-forming sponges and 
corals [17] as well as early life stages of a wide range of species [18]. In addition, increasing temperatures may also contribute to higher frequencies of disease outbreaks as warm-water microbial pathogens are expected to spread $[19,20]$.

The increase in seawater temperature is altering biogeographic boundaries and leading to a meridionalization of the Mediterranean Sea [21] with northward shifts of species[7,22].Changes include an increase in abundance of eurythermal (i.e. wide thermal range tolerant) species and a decrease in cold stenothermal (i.e. narrow thermal range tolerant) species as well as northward species shifts and increase in mass mortalities during unusually hot summers [9]. For example, warm-water fish such asbarracuda(Sphyraena spp.),groupers (Epinephelus spp.), andround sardinella (Sardinellaaurita) have spread northwestwards. Certain cold water species have been replaced, for example the distribution of the cave-dwelling mysid(Hemimysisspeluncola) has contracted and been replaced by the warm-water mysid $H$. margalefi ([22]).

\section{Invasive Species}

Invasive warm water species of algae, invertebrates and fish are increasing their geographical ranges [23,24]. These tropical fauna and flora now form a significant portion of the biota in the Southern Mediterranean [25] where nearly half of the trawl catches along the Levantine coast consists of fish originating from the Red Sea [9,26]. Most of the 955 alien species recorded so far have been found in the Eastern Mediterranean [27] where many are detrimental to fisheries although some are now targeted commercially. In Cyprus, for example, the invasive puffer fishLagocephalussceleratus (Tetraodontidae) is now outcompeting native fish and their prey, such as the Octopus vulgaris (Octopodidae) and squid, which are becoming increasingly scarce [28]. 


\section{Habitat loss/ degradation}

Habitat destruction is one of the most pervasive threats to the diversity, structure and function of marine coastal ecosystems, leading to lower abundances and species richness and often allowing opportunistic species to prosper [29]. Habitat fragmentation can also impair the integrity, connectivity and functioning of large-scale processes leading to decreasing population stability and isolation of communities [30].

In the Mediterranean Sea, coastal habitats such as seagrass meadows, mollusc reefs (created by oysters, vermetids and mussels), coralligenousmaerl formations, and macroalgal assemblages on shallow reefs are examples of complex and highly biodiverse and productive ecosystems. They supply food resources, nurseries and shelter for species that are protected by international conventions, directives and action plans. Species invasion, unsustainable fisheries and aquaculture, sedimentation increase, water degradation, uncontrolled coastal tourism concentration, and urbanization can all have negative impacts on Mediterranean Sea habitats and associated species assemblages [8]. Continued loss of habitats to coastal development has triggered several international protective measures such as the development of Marine Protected Areas (MPAs), but their efficacy is questioned for improving resilience to climate change and acidification[31,32] as habitat loss continues apace.

\section{Overfishing and aquaculture impacts}

Overfishing in the Mediterranean Sea has had severe impacts both through direct overexploitation of targeted species such as small pelagics[33] and the Bluefin tuna [34]as well as through the damage of habitats and ecosystems. Trawling gear, dredges can degrade seabed habitats and harm non-target species such as cetaceans and turtles [35]. Bottomtrawling is a non-selective fishing method that causes a large mortality of discarded benthic 
invertebrates which can cause habitat destruction [35-37]. Massive prey depletion also leads to population declines of top predators such as marine mammals [38].

Given human population growth and the global decline in fisheries, aquaculture is predicted to increase to meet growing demand [39]. Some finfish farming can have a number of environmental effects on surrounding and downstream ecosystems [40]. Dissolved wastes increase the nutrient loading of the area and particulate wastes increase sediment deposition in coastal waters. The impacts of fishfarming on benthos in the Mediterranean vary considerably depending on site characteristics in particular on current and depth where the cages are located. Large-scalePosidoniaoceanica losses adjacent to fish farm cages have been reported across the Mediterranean [41].

\section{Ocean acidification in the Mediterranean Sea}

The Mediterranean Sea is low in nutrients except where coastsare affected by eutrophication, such as the Adriatic Sea. There is a general eastward pattern of increasing sea surface water temperature $(\mathrm{SST})$, salinity $(\mathrm{S})$, oxygen concentration, total carbon $\left(C_{\mathrm{T}}\right)$ and total alkalinity $\left(A_{\mathrm{T}}\right)$. Seasonal $\mathrm{pH}$ amplitudes can be very large (Fig. 6), particularly in the relatively shallow North Adriatic Sea,which also has a large seasonal temperature range. The SST, S, $A_{\mathrm{T}}$ patterns are mainly explained by evaporation coupled with highly alkaline freshwaters entering the basin from rivers and the Black Sea[42-44].The anthropogenic $\mathrm{CO}_{2}$ concentration for the Mediterranean Sea[42,45,46] is higher than in the Atlantic Ocean and the Pacific Ocean $[47,48]$ at the same latitude, and higher than other marginal seas in the northern hemisphere [49]. The high uptake of anthropogenic $\mathrm{CO}_{2}$ in the Mediterranean Sea isrelated to its active overturning circulation [50]and relatively high $A_{\mathrm{T}}$ and temperature[51,52]. A dataset from the Northwestern Mediterranean Sea indicates a $\mathrm{pH}$ 
reduction of approximately $0.0018 \mathrm{pH}$ unit per year [2,3] from 1994 to 2006 . For the next fifty years, an extrapolation of data from thistime series, (Dyfamed, central Ligurian Sea),leads to an estimated $\mathrm{pH}$ decrease of $0.07-0.13$ units corresponding to a decreasing rate of $0.002 \pm 0.001 \mathrm{pH}$ units per year[53].

\section{Ocean acidification impacts on fisheries and aquaculture}

\subsection{Direct effects on fish and shellfish}

\section{Shellfish}

Bivalve mollusks are ecologically and commercially importantwithshellfish aquaculture is a particularly important activity for Mediterranean countries. However relatively few experimentsof the impact of ocean acidification have been undertaken in Mediterranean waters despite the hydrological and carbonate chemistry conditions having the potential to influence the sensitivity or resilience of bivalve species to ocean acidification. For instance, experiments conducted on the Atlantic side of the Gibraltar strait (Ria de Formosa, Portugal) in waters with high alkalinity levels showed that a $\mathrm{pH}$ reduction of 0.3 to 0.7 did not lead to significant reduction in growth of Mediterranean clams and mussels (Ruditapesdecussatus, Veneridae and M. galloprovincialis; [54,55]). Indeed, in these studies, higher alkalinity levels prevented any undersaturation with respect to aragonite and calcite in all treatments.

Large decreases in $\mathrm{pH}$ have, however, been showed to alter bivalve growth, even in Mediterranean waters. Michaelidis et al. [53], showed a significant reduction in shell and soft body growth of the Mediterranean mussel Mytilusgalloprovincialis(Mytilidae) following a long-term ( 90 days) laboratory exposure to $\mathrm{pH} 7.3$ [56], a level projected in the next 300 years.Similarly, in the Adriatic Sea, slight but significant reduced survival[57], growth and calcification of two marine bivalves (juveniles of the clam Chamaleagallina 
and of the mussel Mytilusgalloprovincialis)were induced by a relatively large decrease in $\mathrm{pH}(0.7)$ after 6 months of exposure [58].

Interestingly, Rodolfo-Metalpaet al.[59]showed that gross calcification rates by Mediterranean mussel (as measured by the incorporation of ${ }^{45} \mathrm{Ca}$ ) was not impacted by $\mathrm{pH}$ during most of the year, except in summer when calcification rates were significantly lower at $\mathrm{pH}$ 7.4, suggestingsynergetic negative effects of acidification and warming (for review [60]). Short-term factorial experiments performed in the Adriatic Sea revealed that acidification caused alterations in immunological parameters of adult bivalves, under suboptimal conditions of temperature [57]. In the frame of the MedSeA project (http://medseaproject.eu; [61]), a year-long experiment onthe Mediterranean mussel Mytilusgalloprovincialisshowed no lethal effects ofhypercarpnia (i.e.condition of elevated $\mathrm{CO}_{2}$ in the seawater), while all mussels exposed to $3^{\circ} \mathrm{C}$ above ambient temperature died in August (temperature $>27^{\circ} \mathrm{C} ;[14]$ ). Furthermore, ocean acidification had an effect on shell and soft-body growth in summer when temperature reached sub-optimal levels in the unperturbed temperature treatment, with significant loss of the periostracum, a protective organic layer covering the outer shell.

The impact of ocean acidification on molluscancalcifiers is not limited to growth and calcification as several physiological processes are affected by hypercapnia, as mollusks capacities to compensate for changes in acid-base status due to elevated $\mathrm{CO}_{2}$ is believed to be somewhat limited.Michaelidiset al.[56] showed that long-term hypercapnia at $\mathrm{pH} 7.3$ caused a permanent reduction in haemolymph $\mathrm{pH}$ in mussels from Greece and suggested that these organisms increase haemolymph bicarbonate levels derived mainly from enhanced shell dissolution in order to limit the degree of acidosis. In contrast, although intracellular $\mathrm{pH}$ decreased significantly with environmental hypercapniain the short-term, it was restored to normal levels in most tissues after several days of exposure. 
The decrease in haemolymph $\mathrm{pH}$ was suspected to be the main reason of the decrease in oxygen consumption rates as observed at low $\mathrm{pH}$, due to the inhibition of net proton transport across the cell membrane, a metabolic depression that is consistent with results from experiments performed on other marine invertebrates (e.g. [62]). Increased rates of ammonia excretion and associated decreases of $\mathrm{O}: \mathrm{N}$ ratio suggested that the organisms exposed to low $\mathrm{pH}$ conditions increased their use of proteins as metabolic substrates. This could be responsible for damaging their cellular protein pool and therefore contribute to the observed drop in somatic growth.

Although very few data are currently available for bivalves in the Mediterranean Sea and none, to the best of our knowledge, on oysters that represent a significant part of Mediterranean shellfish production, it appears from laboratory experiments that lowered growth or altered physiology are not always observed under elevated seawater $\mathrm{CO}_{2}$ conditions. Furthermore, evidence suggests that, at leastfor Mediterranean mussels [12, 57],warming and acidification will both extendthe temporal window when these organisms are exposed to sub-optimal conditions, most likely leading to decreased survival and growth in the coming decades.

Additionally, recruitment of organisms from the plankton is impaired in many groups as the larval stage is especially vulnerable to the effects of ocean acidification on their development - this appears to be especially true for molluskan species with implications for the shellfish industries [63]. In their recent review, Gazeauet al.[60] reported that embryonic and larval shellfish stages mainly respond negatively to ocean acidification regarding survival, development rate, growth and calcification. For oysters and mussels, studies showed that the negative effects of ocean acidification coincided with the beginning of shell formation (the trochophore stage), with no real impacts detected prior to this time and the decrease of larval development and growth is correlated to carbonate ions 
availability than to $\mathrm{pH}$ or aragonite saturation state[64-66]. Although mollusk embryo and larval responses to acidificationare not fully understood[67], the vulnerability of early-life stages is a potential bottleneck for population dynamics, and a concern for exploited mollusk [68].However, no studies have been performed on the effects of ocean acidification (and warming) on the larval development of bivalve species in the Mediterranean Sea.

\section{Fish}

Few studies have investigated the effect of hypercarpnia on Mediterranean fishes precluding a direct assessmentof the risk posed by ocean acidification on these marine resources.Nevertheless, based on the sparse current knowledgeacquired in other regions, mostly derived from laboratory-based experiments, the general understanding is thatadult fishes are not directly impaired by ocean acidification as their physiological performance allows them to cope with extracellular acidosis caused by ocean acidification (e.g. [69]). Furthermore, in contrast to shellfish, they are motile species and they can respond to acidification by shifting their geographic and depth ranges of distribution as already observed as a response to seawater warming. However, their efficienthypercania compensation capacity does not prevent from downstream effects, for instance resulting in alterations of physiological and behavioral performances (see review [70]). As recently shown, $\mathrm{CO}_{2}$ levels $<1000 \mu$ atm can interfere with crucial sensory behaviour in juvenile coral reef fish [71-73] or in sharks [74]. Surprisingly, one study showed a stimulation of breeding activity and reproduction success in the clownfish Amphiprionmelanopus (Pomacentridae) when exposed to $\mathrm{CO}_{2}$ above $580 \mu$ atm[75]. These limited results do not allow an evaluation of the long-term consequences of the higherenergy cost for acid-base compensation and subsequent limit aerobic scope on fish fitness and individual performance [76]. 
A few direct effects of ocean acidification have been found on early-life stagesof fish, which are considered vulnerable because of the non-maturity of their physiological systems and acclimation capacities [76]. A decrease of survival and growth rate has been observed in an estuarine fish (Menidiaberyllina, Atherinopsidae) when exposed to high$\mathrm{CO}_{2}(1000 \mu \mathrm{atm})$ just after egg fertilization, potentially affecting recruitment success at the population scale [77]. At $\mathrm{CO}_{2}$ levels above $5000 \mu \mathrm{atm}$, survival of Pacific tuna Thunnusalbacareslarvae is affected[78]. Altered behaviour and otolith growth under highCO ${ }_{2}$ have been also highlighted, although responses appear as species-specific [79-81]. There are indications that increased $\mathrm{CO}_{2}$ can negatively affect the metabolism and development of embryos of the Atlantic herring (a cold-water clupeid fish),Clupeaharengus (Clupeidae; [82]). On the other hand, recent data suggest that early life stages of cultured species such as the seabass, Dicentrarchuslabrax (Moronidae) are resilient to ocean acidification[83].

Regarding fished or farmed species inthe Mediterranean Sea, two studies suggest that adultsof the seabreamSparusaurata (Sparidae) are tolerant to seawater hypercarpnia and fully compensatefor extracellular acidosis even when exposed to $\mathrm{CO}_{2}$ levels above $3000 \mu$ atm[84]. Furthermore, at lower levels (2000 $\mu \mathrm{atm})$, a hypercalcification of otolith but no variation of somatic growth have been observed in juveniles of seabream suggesting their resilience to the ongoing ocean acidification [85].

In the Northwestern Mediterranean Sea, landings of warm-water clupeid anchovies (Engraulisencrasicolus, Engraulidae) and sardines (Sardinapilchardus, Clupeidae)are negatively correlated with high sea surface temperatureand low river runoff,that directly affect survival, growth, condition and reproduction of fish and impact recruitment success through lowered biological productivity in coastal areas suggesting that reproduction and recruitment success are affected by high temperature anomalies and land-based nutrient- 
related productivity of the coastal area [86]. In this context, this implies that warming may impact small pelagic populations in the Mediterranean Sea.No experimental studies have considered the cumulative effects of warming and acidification on fishes of commercial interest in the Mediterranean Sea.

\subsection{Indirectimpacts of ocean acidification}

In the previous section, the potential direct effects of ocean acidification and warming on commercial species in the Mediterranean have been considered. In the following section indirect effects of ocean acidification on fisheries and aquaculture will be considered.,These will be(i) changes to biodiversity, (ii) habitat loss and (iii) trophic web alteration.

\section{Changes tobiodiversity}

Thelarge biodiversity in the Mediterranean Seaprovides "use value" through sustainable use of marine organisms(e.g. algae and sponges supply a large variety of bioactive metabolites some of which are used to treat human diseases). This sea provides a wide range of food (highquality protein, minerals and vitamin D and omega-3 fatty acids) with antioxidant properties and cardio and cancer protective effects and ornamental resources. Additionally, biodiversity generates a "non-use value" as bequest and existence value [87]. For instance, Langford et al.[88] report a non-market valuation study in the Aegean areaofthe public's willingness to pay (WTP) for conservation ofpatrimonial species such as the Mediterranean monk seal (Monachusmonachus, Phocidae), classified as the most endangered seal species in the world.See Nunes and van den Bergh [89] or Remoundou et al. [90] for other studies on bequest and existence value of marine species. Large biodiversity enhancesintrinsic capacityfor adaptation 
of species (genetic diversity), resilience of ecosystem (specific richness within ecological guilds) and adaptation of dependent-population fostering shifts of fisheries targets.

\section{Habitat loss}

Many plants and invertebratesin the Mediterranean Seaform unique assemblages that provide essential habitats for fish and crustaceans and contribute significantly to the ecosystem functioning. Photosynthetic organisms, using $\mathrm{CO}_{2}$ as a source for organic matter production, could potentially benefit from its higher availability. While Israel and Hophy[91] showed that a $\mathrm{pH}$ of 7.8 does not have any effect on growth and photosynthesis in a wide range of Mediterranean algae, Invers et al. [92] reported that this level of acidification enhanced photosynthesis in the important habitat forming Mediterranean seagrassesPosidoniaoceanica (Posidoniaceae) and Cymodoceanodosa (Cymodoceaceae). Field studies offVulcano and Ischia showed that seagrasses and certain seaweeds are able to benefit from elevated $\mathrm{CO}_{2}$ levels [93-95] and extend their cover area to the detriment of the diversity and abundance of calcareous algae. Calcifying coralline algae can also be important habitat formers and were found to be adversely affected by elevated $\mathrm{CO}_{2}$ conditions, particularly when combined with high temperatures (seasonal temperature $+3^{\circ} \mathrm{C}[96]$ ). More recently, Kroeker et al. [97]showed that calcareous species might be physiologically able to persist in $\mathrm{pH}$ condition predicted for the near-future ocean but suffer from the development of a higher competitive ability of fleshy, non-calcareous seaweeds. Overall, current studies indicate that ocean acidification will cause major shifts in the microalgae and seaweed communities. The potential loss of some of these organisms is a great concern as they form important habitats for fish, shellfish and a wide range of other organisms.

Results obtained in the framework of the MedSeA project also suggest dramatic changes across ecosystems and taxa under ocean acidification and warming conditions. Thus, sea 
grass meadows are expected to suffer from elevated seawater temperature and invasion by non-indigenous algae species, which benefit from increased $\mathrm{CO}_{2}$ and elevated temperature. Whilst calcified organisms generally fare badly as $\mathrm{CO}_{2}$ levels increase, some can proliferate in an uncalcified form (e.g.Padina spp., Dictyotaceae; [94]).

Moreover, the slow growth or even extinction of key calcifiers may detrimentally affect major bio-construction on vermetid reefs and coralligene reefs where these supply the cementing calcium carbonate that keeps these reefs intact [98]. Vermetid reefs along the Levant coast are already facing extinction, which is likely to lead tomajor loss of biodiversity and shore erosion. Calcifying corals that form important habitats for fish, supporting their own fisheries, attracting recreational tourism [99] and supporting local economies appear to be particularly vulnerable [59]. For example, it has been recently demonstrated that there are detrimental effects of ocean acidification on the economically important Mediterranean red coral endemic speciesCoralliumrubrum, Coralliidae, mainly due to the elevated solubility of its $\mathrm{Mg}$-calcite skeleton[100]. In turn, the growth and calcification of cold-water corals maynot being affected by $\mathrm{CO}_{2}$ levels projected for the end of century after long-term exposure [101,102]. Nevertheless, considering that information on this acclimation of calcification in natural environment are scarce and that corals live close to their upper thermal limits in Mediterranean Sea, the fate of these deep-sea builders of hotspot biodiversity remain uncertain.

As both calcifying and non-calcifying habitat-formingspecies are likely to suffer under warming and acidification this will lead to malfunction of the respective habitats and have knock-on ecological effects, limiting the biodiversity and functional diversity of ecosystem, i.e. limiting resources for targeted species and nursery grounds and potentially altering the sustenance of fish stocks.

Oligotrophic coastal habitats such as those in the Mediterranean Sea are dominated by slow 
growing species and intricate food webs. Habitat losses can be considered irreversible, as it would take centuries following the cessation of disturbances for ecosystems to return to their original state.

\section{Trophic web changes}

The abundance of marine resources, including both mollusks and fishes, are strongly dependent on the structure and functioning of the regional trophic webs, and could be indirectly impacted if the increasing $\mathrm{CO}_{2}$ levels affected abundance and quality of the lowest trophic levels (i.e. phyto- and zooplankton). Benthic food webs in the Mediterranean are supported by the productivity ofmeadows of the seagrassPosidoniaoceanica. This benthic productivity could decrease by the end of the century due to the negative impacts of raised seawater temperature directly on the seagrass and through a significant loss of epiphytic communities by higher $p \mathrm{CO}_{2}$ conditions foreseen[103]. Recent studieshighlighted a possible shift in pelagic productivity from large phytoplankton towards the smallest pico- and nanoplankton as a result of future ocean acidification - see Riebesellet al.[104]and warming [105].

The cell density and biodiversity of coccolithophoreswere also found to decrease along a natural $\mathrm{pH}$ gradient off Vulcano Island [106].In addition, an impact on the calcareous phytoplankton dominant species has been already observed in a time series in the Gulf of Lyon mainly linked to ocean acidification [2]. Nevertheless, mesocosm experiments carried out in oligotrophic area in Mediterranean demonstrated that ocean acidification did not affect the primary, POC, DOC production and community respiration [107], as the plankton communities are first limited by the nutrient availability. Such a substantial change in the base of the pelagic food web will have direct consequences for the structure and functioning of the higher levels of food web. At the next trophic level, zooplankton is a major dietary component for fish, including small pelagic such as sardines. The larval stage of 
pteropodsCavoliniainflexia (Cavoliniidae) appeared directly impacted at $\mathrm{pH}$ projected for the end of century, and displayed malformations and lower shell growth [108]. While it had been thought that that copepods would be not affected by ocean acidification, recent work questions the ability of the Mediterranean Acartiaclausi (Acartiidae) to cope with combined stress of acidification and warming[109].

Field studies at the community scale highlighted that decreasing $\mathrm{pH}$ tends to lead to a decrease in the species richness and biomass causing a simplification of the trophic web functioning [110]. In Greece, ocean acidification around natural $\mathrm{CO}_{2}$ vents stimulates macro-algal communities but this increase in biomass is controlled by herbivorous species, with shifts in abundance and composition from sea urchin to herbivorous fish (Baggini et al., 2015).This observation suggests that a bottom-up effect of ocean acidification on seaweed biomass could be controlled by a top-down process consisting of a shift within the same trophic level from species vulnerable to $\mathrm{CO}_{2}$ to more tolerant species. This shift of community to a few generalist species could lead to another cause for concern, that is a proliferation of non-calcifying cnidarians (jellyfish and anemones) resilient to or benefiting from warming and/or acidification [111,112]. Finally, recent studied performed in sedimentary habitats in the natural $\mathrm{CO}_{2}$ gradients off Vulcano, Italy, have revealed increased ocean $\mathrm{CO}_{2}$ is associated with changes in sediment bacterial community composition but that most of these organisms are resilient [113]. The consequences of these microbial diversity shifts on the benthic trophic web and biogeochemical cycles remain still unclear. As the Mediterranean Sea is threatened by rising $\mathrm{CO}_{2}$, it becomes increasingly essential to assess the socio-economic value of these important systems, including ocean acidification impacts on ecosystem functioning and trophic web changes. 


\section{Human health impacts}

Beyond the impact of ocean acidification on the production of marine resources, the quality of seafood might be compromised by future ocean conditions and may increase the safety risk for human consumers. Concomitantly with increased eutrophication and stratification of the Mediterranean Basin, ocean acidification is expected to foster Harmful Algal Bloom (HAB) in coastal waters[114,115]. Proliferation of these harmful microalgae can cause damage to the environment directly by affecting exposed organisms as well as threaten human health through contaminated seafood consumption [116]. Temperature appears as the main factor driving harmful algae abundance, as observed for ciguatoxinGambierdiscusspp, Goniodomataceae[117] or saxitoxinAlexandriumcatenella, Goniodomataceae[118]. In the Mediterranean Sea, the palytoxin-producing dinobiontOstreopsis ovate, Ostreopsidaceae is extending its distribution, with definite consequences on human health (irritation, cough, fever and respiratory problems; [119]). Moreover, Gambierdiscustoxicus, the main causative agent of ciguatera poisoning, normally has a tropical or subtropical distribution but has recently been reported in waters around Crete. While there are few studies investigate the potential impact of ocean acidification on the HABs, it has been recently demonstrated that $\mathrm{CO}_{2}$ combined with limited nutrient enhanced karlotoxin and domoic acid production byKarlodiniumveneficum, Kareniaceae[120] andPseudonitzschiafraudulenta, Bacillariaceae[121], respectively.

Ocean acidification and warming will occur in a background of chronic contamination of the coastal area through human discharges of contaminants. The changes of seawater chemistry caused by increased $\mathrm{CO}_{2}$ can modify the bioavailability of contaminants such as trace elements [122]. As a consequence of acidification, the bioaccumulation of metals in organisms such as cephalopod or bivalves is expected to rise under a constant contamination pressure[123-127]. Beyond the direct toxicological risk for marine animals, 
seafood safety with regard to human consumers might be compromised by increases of both total metal concentrations and of the bioaccessible fraction of contaminants (Belivermis et al., unpublished data). Indeed, oysters can accumulate high levels oftrace elements, such as $\mathrm{Zn}$, in their soft tissues in the form of metabolically inert metal-rich granules [128]. These $\mathrm{Mg} / \mathrm{Ca}$ carbonate granules are known for their potential for buffering the extracellular $\mathrm{pH}$ [129] and thus might be easily dissolved when oysters are experiencing hypercapnia. In this context, the ocean acidification mayimpact strategies for metal detoxification and thus the Trophically Available Fraction (TAM) that drives theirbioaccessibility and transfer of these metals to higher trophic level.

\section{Reflections and conclusive remarks}

Future ocean acidificationand increased water temperatures, if global $\mathrm{CO}_{2}$ emissions to the atmosphere continue unabated, area threat to the Mediterranean Sea and will negatively impact its biodiversity and productivity and in turn impact key social and economic services it provides human communities in the region (e.g. shellfish aquaculture, fisheries and tourism).

Key messages emerge from our analysis:

1.A greater understanding of how marine systems are affected by ocean acidification and warming is required through setting up long-term, basin scale monitoring of carbonate system dynamics and regular socio-surveying of Mediterranean warming and acidification impacts on selected production sectors.

2. More information on the responses of local marine species of high economic interest, including both fish and shellfish,and the ecosystems and food webs they depend on to both ocean acidification and warming is required. 
3.Projections of future acidification and warming in regions supporting important fisheries,aquaculture and tourist industries is required to helptheir timely adaptation to a changing sea. .

4. Enhance adaptive capacity within the fisheries and aquaculture sectors, especially in the southern Mediterranean basin where dependence on seafood for animal protein source and income is strong requires development through:

a)technical support and advice to the aquaculture sector in monitoring the risks associated with acidification and warming and understanding future projections, risk maps, risk analysis methods and how they may change with time and levels of acidification and warming

b) development of best practices for adaptive management

c) selection of resistant species or strains to increasing acidification and warming.

d) development of a communication strategy through public-private-partnerships of stakeholders so that there is an exchange of knowledge with parties or sectors most vulnerable to a changing Mediterranean Sea.

5. An involvement of all stakeholders in the societal and industry response to a changing Mediterranean Sea including marine and coastal managers, conservation practitioners, industry representatives, science policy advisors and policy makers, and other stakeholders and end-users, mainly from countries bordering the Mediterranean Sea. This approach can often determine the success or failure of a policy action [130].

6. An integrated economic valuation of other key economic sectors other than fisheries, such as tourism, is neededto help put an economic value to the losses that may be incurred by increasing acidification and warming of the Mediterranean Sea so that policy makerswill have the costs/benefits of policy action as well as the costs of policy inaction with regard to mitigation of and/or adaptation to acidification and warming. . 


\section{Acknowledgments}

The authors are very grateful to Fabio Massa for his fruitful contribution to this work. The authors thank the Centre Scientifique de Monaco and the International Atomic Energy Agency for permitting the scientific discussions during the international workshop "Bridging the Gap between Ocean Acidification Impacts and Economic Valuation" organized in Monaco the 11-13 November 2012.The authors thank the FP7 European project on Mediterranean Sea Acidification in a changing climate (MedSeA - 265103) for the information provided and Luís Rodrigues, Maoz Fine, Franck Touratier and Catherine Goyet for their comments and feedback on previous versions of this document. This study was conducted as part of the Centre Scientifique de Monaco research program, funded by the Government of the Principality of Monaco. The International Atomic Energy Agency is grateful to the Government of the Principality of Monaco for the support provided to its Environment Laboratories. The authors have no conflict of interest to declare. Figures 1 to 5 have been performed using $\mathrm{R}$ freeware[131] and the packages "marmap"[132] and “plotrix”[133]. 


\section{References}

[1] C.N. Bianchi, and C. Morri, Marine biodiversity of the Mediterranean Sea: Situation, problems and prospects for future research, Mar. Pollut. Bull. 40 (2000) 367-376.

[2] K.J.S. Meier, L. Beaufort, S. Heussner, and P. Ziveri, The role of ocean acidification in Emilianiahuxleyi coccolith thinning in the Mediterranean Sea, Biogeosciences 11 (2014) 2857-2869.

[3] E.L. Howes, L. Stemmann, C. Assailly, J.-O. Irisson, M. Dima, J. Bijma, and J.-P. Gattuso, Pteropod time series from the North Western Mediterranean (1967-2003): impacts of pH and climate variability, Mar. Ecol. Prog. Ser. 531 (2015) 193-206.

[4] J. Sacchi, Analyses des activités économiques en Méditerranée: secteurs pêcheaquaculture, Plan Bleu, Valbonne, 2011.

[5] GFCM, Eighth Session of the Committee on Aquaculture: Trend and issues of aquaculture in the Mediterranean and Black Sea., Paris, France, 2013.

[6] D.D. Gambaiani, P. Mayol, S.J. Isaac, and M.P. Simmonds, Potential impacts of climate change and greenhouse gas emissions on Mediterranean marine ecosystems and cetaceans, J. Mar. Biol. Assoc. U. K. 89 (2009) 179-201.

[7] CIESM, Climate warming and related changes in Mediterranean marine biota, CIESM Workshop Monographs, Monaco, 2008.

[8] J. Claudet, and S. Fraschetti, Human-driven impacts on marine habitats: A regional metaanalysis in the Mediterranean Sea, Biol. Conserv. 143 (2010) 2195-2206.

[9] M. Coll, C. Piroddi, J. Steenbeek, K. Kaschner, F.B.R. Lasram, J. Aguzzi, E. Ballesteros, C.N. Bianchi, J. Corbera, T. Dailianis, Danovaro, M. Estrada, C. Froglia, B.S. Galil, J.M. Gasol, R. Gertwagen, J. Gil, F. Guilhaumon, K. Kesner-Reyes, M.-S. Kitsos, A. Koukouras, N. Lampadariou, E. Laxamana, C.M.L.-F.d.l. Cuadra, H.K. Lotze, D. Martin, D. Mouillot, D. Oro, S. Raicevich, J. Rius-Barile, J.I. Saiz-Salinas, C.S. Vicente, S. Somot, J. Templado, X. Turon, D. Vafidis, R. Villanueva, and E. Voultsiadou, The biodiversity of the Mediterranean Sea: estimates, patterns, and threats, PLoS ONE 5 (2010) e11842.

[10] X. Durrieu de Madron, C. Guieu, R. Sempéré, P. Conan, D. Cossa, F. D'Ortenzio, C. Estournel, F. Gazeau, C. Rabouille, L. Stemmann, S. Bonnet, F. Diaz, P. Koubbi, O. Radakovitch, M. Babin, M. Baklouti, C. Bancon-Montigny, S. Belviso, N. Bensoussan, B. Bonsang, I. Bouloubassi, C. Brunet, J.F. Cadiou, F. Carlotti, M. Chami, S. Charmasson, B. Charrière, J. Dachs, D. Doxaran, J.C. Dutay, F. Elbaz-Poulichet, M. Eléaume, F. Eyrolles, C. Fernandez, S. Fowler, P. Francour, J.C. Gaertner, R. Galzin, S. Gasparini, J.F. Ghiglione, J.L. Gonzalez, C. Goyet, L. Guidi, K. Guizien, L.E. Heimbürger, S.H.M. Jacquet, W.H. Jeffrey, F. Joux, P. Le Hir, K. Leblanc, D. Lefèvre, C. Lejeusne, R. Lemé, M.D. Loÿe-Pilot, M. Mallet, L. Méjanelle, F. Mélin, C. Mellon, B. Mérigot, P.L. Merle, C. Migon, W.L. Miller, L. Mortier, B. Mostajir, L. Mousseau, T. Moutin, J. Para, T. Pérez, A. Petrenko, J.C. Poggiale, L. Prieur, M. Pujo-Pay, V. Pulido, P. Raimbault, A.P. Rees, C. Ridame, J.F. Rontani, D. Ruiz Pino, M.A. Sicre, V. Taillandier, C. Tamburini, T. Tanaka, I. Taupier-Letage, M. Tedetti, P. Testor, H. Thébault, B. Thouvenin, F. Touratier, J. Tronczynski, C. Ulses, F. Van Wambeke, V. Vantrepotte, S. Vaz, and R. Verney, Marine ecosystems' responses to climatic and anthropogenic forcings in the Mediterranean, Prog. Oceanogr. 91 (2011) 97-166.

[11] N. Marbà, and C.M. Duarte, Mediterranean warming triggers seagrass (Posidonia oceanica) shoot mortality, Glob. Change Biol. 16 (2010) 2366-2375. 
[12] R. Coma, M. Ribes, E. Serrano, E. Jiménez, J. Salat, and J. Pascual, Global warmingenhanced stratification and mass mortality events in the Mediterranean, Proceedings of the National Academy of Sciences 106 (2009) 6176-6181.

[13] A. Anestis, A. Lazou, H.-O. Pörtner, and B. Michaelidis, Behavioral, metabolic, and molecular stress responses of marine bivalve Mytilusgalloprovincialis during long-term acclimation at increasing ambient temperature, Am. J. Physiol. Regul. Integr. Comp. Physiol. 293 (2007) R911-R921.

[14] F. Gazeau, S. Alliouane, C. Bock, L. Bramanti, M. López Correa, M. Gentile, T. Hirse, H.O. Pörtner, and P. Ziveri, Impact of ocean acidification and warming on the Mediterranean mussel (Mytilusgalloprovincialis), Front. Mar. Sci. 1 (in press) 62

[15] M. Ramón, J. Cano, J.B. Peña, and M.J. Campos, Current status and perspectives of mollusc (bivalves and gastropods) culture in the Spanish Mediterranean, Bol. Inst. Esp. Oceanogr. 21 (2005) 361-373.

[16] E. Díaz-Almela, N. Marbà, R. Martínez, R. Santiago, and C.M. Duarte, Seasonal dynamics of Posidoniaoceanica in Magalluf Bay (Mallorca, Spain): Temperature effects on seagrass mortality, Limnol. Oceanogr. 54 (2009) 2170-2182.

[17] J. Garrabou, R. Coma, N. Bensoussan, M. Bally, P. Chevaldonné, M. Cigliano, D. Díaz, J.G. Harmelin, M. Gambi, D. Kersting, J.B. Ledoux, C. Lejeusne, C. Linares, C. Marshal, T. Pérez, M. Ribes, J.C. Romano, E. Serrano, N. Teixido, O. Torrents, M. Zabala, Z. F., and C. Cerrano, Mass mortality in Northwestern Mediterranean rocky benthic communities: effects of the 2003 heat wave, Glob. Change Biol. 15 (2009) 1090-1103.

[18] M. Byrne, Impact of ocean warming and ocean acidification on marine invertebrate life history stages: vulnerabilities and potential for persistence in a changing ocean, Oceanogr. Mar. Biol. 49 (2011) 1-42.

[19] R. Danovaro, S.F. Umani, and A. Pusceddu, Climate change and the potential spreading of marine mucilage and microbial pathogens in the Mediterranean Sea, PLoS ONE 4 (2009) e7006.

[20] Y. Martin, J.L. Bonnefont, and L. Chancerelle, Gorgonians mass mortality during the 1999 late summer in French Mediterranean coastal waters: the bacterial hypothesis, Water Res. 36 (2002) 779-782.

[21] P. Francour, C.F. Boudouresque, J.G. Harmelin, M.L. Harmelin-Vivien, and J.P. Quignard, Are the Mediterranean waters becoming warmer? Information from biological indicators., Mar. Pollut. Bull. 28 (1994) 523-526.

[22] P. Chevaldonné, and C. Lejeusne, Regional warming-induced species shift in north-west Mediterranean marine caves, Ecol. Lett. 6 (2003) 371-379.

[23] C.N. Bianchi, Biodiversity issues for the forthcoming tropical Mediterranean Sea, Hydrobiologia 580 (2007) 7-21.

[24] C. Lejeusne, P. Chevaldonné, C. Pergent-Martini, C.F. Boudouresque, and T. Pérez, Climate change effects on a miniature ocean: the highly diverse, highly impacted Mediterranean Sea, Trends Ecol. Evol. 25 (2010) 250-260.

[25] F.B.R. Lasram, and D. Mouillot, Increasing southern invasion enhances congruence between endemic and exotic Mediterranean fish fauna, Biol. Invasions 11 (2009) 697-711.

[26] M.J. Costello, M. Coll, R. Danovaro, P. Halpin, H. Ojaveer, and P. Miloslavich, A cencus of marine biodiversity knwoledge, resources, and future challenges, PLoS ONE 5 (2010) e12110.

[27] A. Zenetos, I. Siokou-Frangou, O. Gotsis-Skretas, and S. Groom, The Mediterranean Sea, EEA. Europe's Biodiversity: biogeographical regions and seas (2002) pp 22.

[28] M. Nader, S. Indary, and L. Boustany, FAO EastMed The Puffer Fish Lagocephalus sceleratus (Gmelin, 1789) in the Eastern Mediterranean, GCP/INT/041/EC - GRE - ITA/TD10, 2012. 
[29] L. Airoldi, D. Balata, and M.W. Beck, The Gray Zone: Relationships between habitat loss and marine diversity and their applications in conservation, J. Exp. Mar. Biol. Ecol. 366 (2008) 8-15.

[30] S.F. Thrush, J.S. Gray, J.E. Hewitt, and K.I. Ugland, Predicting the effects of habitat homogenization on marine biodiversity, Ecol. Appl. 16 (2006) 1636-1642.

[31] J. García-Charton, A. Pérez-Ruzafa, C. Marcos, J. Claudet, F. Badalamenti, L. BenedettiCecchi, J. Falcón, M. Milazzo, P. Schembri, B. Stobart, F. Vendeperre, A. Brito, R. Chemello, M. Dimech, P. Domenici, I. Guala, L. Le Diréach, E. Maggi, and S. Planes, Effectiveness of European Atlanto-Mediterranean MPAs: do they accomplish the expected effects on populations, communities and ecosystems?, Journal for Nature Conservation 16 (2008) 193-221.

[32] M. Montefalcone, G. Albertelli, C. Morri, V. Parravicini, and C.N. Bianchi, Legal protection is not enough: Posidonia oceanica meadows in marine protected areas are not healthier than those in unprotected areas of the northwest Mediterranean Sea, Mar. Pollut. Bull. 58 (2009) 515-519.

[33] I. Palomera, M.P. Olivar, J. Salat, A. Sabatés, M. Coll, A. García, and B. Morales-Nin, Small pelagic fish in the NW Mediterranean Sea: An ecological review, Prog. Oceanogr. 74 (2007) 377-396.

[34] B.R. MacKenzie, H. Mosegaard, and A.A. Rosenberg3, Impending collapse of bluefin tuna in the northeast Atlantic and Mediterranean, Conserv. Let. 2 (2009) 26-35.

[35] S. Tudela, Ecosystem effects of fishing in the Mediterranean: an analysis of the major threats of fishing gear and practices to biodiversity and marine habitats, FAO, Studies and Reviews. General Fisheries Commission for the Mediterranean, Roma, Italy, 2004.

[36] J. Hall-Spencer, C. Froglia, R.J.A. Atkinson, and P.G. Moore, The impact of Rapido trawling for scallops, Pecten jacobaeus (L.), on the benthos of the Gulf of Venice, ICES J. Mar. Sci. 56 (1999) 111-124.

[37] A. Pusceddua, C. Fiordelmondo, P. Polymenakou, T. Polychronaki, A. Tselepides, and R. Danovaro, Effects of bottom trawling on the quantity and biochemical composition of organic matter in coastal marine sediments (Thermaikos Gulf, northwestern Aegean Sea), Continental Shelf Research 25 (2005) 2491-2505.

[38] R. Reeves, and G. Notarbartolo di Sciara, The status and distribution of cetaceans in the Black Sea and Mediterranean Sea, IUCN Centre for Mediterranean Cooperation, Malaga, Spain, 2006.

[39] C.M. Duarte, M. Holmer, Y. Olsen, D. Soto, N. Marbà, J. Guiu, K. Black, and I. Karakassis, Will the oceans help feed humanity?, Bioscience 59 (2009) 967-976.

[40] M. Holmer, M. Argyrou, T. Dalsgaard, R. Danovaro, E. Diaz-Almela, C.M. Duarte, M. Frederiksen, A. Grau, I. Karakassis, N. Marbà, S. Mirto, M. Pérez, A. Pusceddu, and M. Tsapakis, Effects of fish farm waste on Posidoniaoceanica meadows: Synthesis and provision of monitoring and management tools, Mar. Pollut. Bull. 56 (2008) 1618-1629.

[41] C. Pergent-Martini, C.-F. Boudouresque, V. Pasqualini, and G. Pergent, Impact of fish farming facilities on Posidoniaoceanica meadows: a review, Mar. Ecol. 27 (2006) 310-319.

[42] S.H. Schneider, S. Semenov, A. Patwardhan, I. Burton, C.H.D. Magadza, M. Oppenheimer, A.B. Pittock, A. Rahman, J.B. Smith, A. Suarez, and F. Yamin, Assessing key vulnerabilities and the risk from climate change, in: M.L. Parry, O.F. Canziani, J.P. Palutikof, P.J.v.d. Linden, and C.E. Hanson (Eds.), Climate Change 2007: Impacts, Adaptation and Vulnerability. Contribution of Working Group II to the Fourth Assessment Report of the Intergovernmental Panel on Climate Change, Cambridge University Press, Cambridge, UK, 2007, 779-810.

[43] G. Cossarini, P. Lazzari, and C. Solidoro, Space-time variability of alkalinity in the Mediterranean Sea, Biogeosciences Discussion 11 (2014) 12871-12893. 
[44] M. Álvarez, H. Sanleón-Bartolomé, T. Tanhua, L. Mintrop, A. Luchetta, C. Cantoni, K. Schroeder, and G. Civitarese, The $\mathrm{CO}_{2}$ system in the Mediterranean Sea: a basin wide perspective, Ocean Sci. 10 (2014) 69-92.

[45] CIESM, Impacts of acidification on biological, chemical and physical systems in the Mediterranean and Black Seas, CIESM Workshop Monographs, Monaco, 2008.

[46] F. Touratier, and C. Goyet, Decadal evolution of anthropogenic $\mathrm{CO}_{2}$ in the northwestern Mediterranean Sea from the mid-1990s to the mid-2000s, Deep Sea Research I 56 (2009) 1708-1716.

[47] K. Lee, S.-D. Choi, G.-H. Park, R. Wanninkhof, T.-H. Peng, R.M. Key, C.L. Sabine, R.A. Feely, J.L. Bullister, F.J. Millero, and A. Kozyr, An updated anthropogenic $\mathrm{CO}_{2}$ inventory in the Atlantic Ocean, Global Biogeochemical Cycles 17 (2003) 1116.

[48] C.L. Sabine, R.A. Feely, R.M. Key, J.L. Bullister, F.J. Millero, K. Lee, T.-H. Peng, B. Tilbrook, T. Ono, and C.S. Wong, Distribution of anthropogenic $\mathrm{CO}_{2}$ in the Pacific Ocean, Global Biogeochemical Cycles 16 (2002) 1083.

[49] K. Lee, C.L. Sabine, T. Tanhua, T.-W. Kim, R.A. Feely, and H.-C. Kim, Roles of marginal seas in absorbing and storing fossil fuel CO2, Energy Environ. Sci. 4 (2011) 11331146.

[50] N. Pinardi, and E. Masetti, Variability of the large scale general circulation of the Mediterranean Sea from observations and modelling: a review, Palaeogeography, Palaeoclimatology, Palaeoecology 158 (2000) 153-173.

[51] J. Palmiéri, J.C. Orr, J.-C. Dutay, K. Béranger, A. Schneider, J. Beuvier, and S. Somot, Simulated anthropogenic $\mathrm{CO}_{2}$ uptake and acidification of the Mediterranean Sea, Biogeosciences Discussion 11 (2014) 6461-6517.

[52] A. Schneider, T. Tanhua, A. Körtzinger, and D.W.R. Wallace, High anthropogenic carbon content in the eastern Mediterranean, J. Geophys. Res. 115 (2010) C12050.

[53] P. Geri, S. El Yacoubi, and C. Goyet, Forecast of Sea Surface Acidification in the Northwestern Mediterranean Sea, Journal of Computational Environmental Sciences Article ID 201819 (2014) 7 pp.

[54] P. Range, M.A. Chícharo, R. Ben-Hamadou, D. Piló, D. Matias, S. Joaquim, A.P. Oliveira, and L. Chícharo, Calcification, growth and mortality of juvenile clams Ruditapesdecussatus under increased $\mathrm{pCO}_{2}$ and reduced $\mathrm{pH}$ : Variable responses to ocean acidification at local scales?, J. Exp. Mar. Biol. Ecol. 396 (2011) 177-184.

[55] P. Range, D. Piló, R. Ben-Hamadou, M.A. Chícharo, D. Matias, S. Joaquim, A.P. Oliveira, and L. Chícharo, Seawater acidification by $\mathrm{CO}_{2}$ in a coastal lagoon environment: Effects on life history traits of juvenile mussels Mytilus galloprovincialis, J. Exp. Mar. Biol. Ecol. 424-425 (2012) 89-98.

[56] B. Michaelidis, C. Ouzounis, A. Paleras, and H.O. Pörtner, Effects of long-term moderate hypercapnia on acid-base balance and growth rate in marine mussels Mytilus galloprovincialis, Mar. Ecol. Prog. Ser. 293 (2005) 109-118.

[57] M. Bressan, A. Chinellato, M. Munari, V. Matozzo, A. Manci, T. Marceta, L. Finos, I. Moro, P. Pastore, D. Badocco, and M.G. Marin, Does seawater acidification affect survival, growth and shell integrity in bivalve juveniles?, Mar. Environ. Res. 99 (2014) 136-148.

[58] P. Range, M.A. Chícharo, R. Ben-Hamadou, D. Piló, M.J. Fernandez-Reiriz, U. Labarta, M.G. Marin, M. Bressan, V. Matozzo, A. Chinellato, M. Munari, N.T.E. Menif, M. Dellali, and L. Chícharo, Impacts of $\mathrm{CO}_{2}$-induced seawater acidification on coastal Mediterranean bivalves and interactions with other climatic stressors, Reg. Environ. Change 14 (Suppl 1) (2014) S19-S30.

[59] R. Rodolfo-Metalpa, F. Houlbreque, E. Tambutté, F. Boisson, C. Baggini, F.P. Patti, R. Jeffree, M. Fine, A. Foggo, J.-P. Gattuso, and J. Hall-Spencer, Coral and mollusc resistance to ocean acidification adversely affected by warming, Nature Climate Change 1 (2011) 308-312. 
[60] F. Gazeau, L.M. Parker, S. Comeau, J.-P. Gattuso, W.A. O'Connor, S. Martin, H.-O. Pörtner, and P.M. Ross, Impacts of ocean acidification on marine shelled molluscs, Mar. Biol. 160 (2013) 2207-2245.

[61] P. Ziveri, Research turns to acidification and warming in the Mediterranean Sea, IMBER Newsletter $\mathrm{n}^{\circ} 20$ (2012).

[62] H.O. Pörtner, A. Reipschläger, and N. Heisler, Acid-base regulation, metabolism and energetics in Sipunculus nudus as a function of ambient carbon dioxide level, J. Exp. Biol. 201 (1998) 43-55.

[63] M. Cigliano, M.C. Gambi, R. Rodolfo-Metalpa, F.P. Patti, and J.M. Hall-Spencer, Effects of ocean acidification on invertebrate settlement at volcanic $\mathrm{CO}_{2}$ vents, Mar. Biol. 157 (2010) 2489-2502.

[64] F. Gazeau, J.-P. Gattuso, M. Greaves, H. Elderfield, J. Peeene, C.H.R. Heip, and J.J. Middelburg, Effect of carbonate chemistry alteration on the early embryonic development of the pacific oyster (Crassostrea gigas), PLoS ONE 6 (2011) e23010.

[65] G.G. Waldbusser, B. Hales, C.J. Langdon, B.A. Haley, P. Schrader, E.L. Brunner, M.W. Gray, C.A. Miller, I. Gimenez, and G. Hutchinson, Ocean acidification has multiple modes of action on bivalve larvae, PLoS ONE 10 (2015) e0128376.

[66] J. Thomsen, K. Haynert, K.M. Wegner, and F. Melzner, Impact of seawater carbonate chemistry on the calcification of marine bivalves, Biogeosciences 12 (2015) 4209-4220.

[67] M. Vihtakari, I.E. Hendriks, J. Holding, P.E. Renaud, C.M. Duarte, and J.N. Havenhand, Effects of ocean acidification and warming on sperm activity and early life stages of the Mediterranean mussel (Mytilusgalloprovincialis), Water 5 (2013) 1890-1915.

[68] S. Dupont, N. Dorey, and M. Thorndyke, What meta-analysis can tell us about vulnerability of marine biodiversity to ocean acidification?, Estuar. Coast. Shelf Sci. 89 (2010) 182-185.

[69] F. Melzner, M.A. Gutowska, M. Langenbuch, S. Dupont, M. Lucassen, M.C. Thorndyke, M. Bleich, and H.O. Pörtner, Physiological basis for high $\mathrm{CO}_{2}$ tolerance in marine ectothermic animals: pre-adaptation through lifestyle and ontogeny?, Biogeosciences 6 (2009) 2313-2331.

[70] R.M. Heuer, and M. Grosell, Physiological impacts of elevated carbon dioxide and ocean acidification on fish, Am. J. Physiol. 307 (2014) R1061-R1084.

[71] S. Bignami, I.C. Enochs, D.P. Manzello, S. Sponaugle, and R.K. Cowen, Ocean acidification alters the otoliths of a pantropical fish species with implications for sensory function, Proc. Natl. Acad. Sci. U. S. A. 110 (2013) 7366-7370.

[72] P.L. Munday, D.L. Dixson, J.M. Donelson, G.P. Jones, M.S. Pratchett, G.V. Devitsina, and K.B. Doving, Ocean acidification impairs olfactory discrimination and homing ability of a marine fish, Proc. Natl. Acad. Sci. U. S. A. 106 (2009) 1848-1852.

[73] S.D. Simpson, P.L. Munday, M.L. Wittenrich, R. Manassa, D.L. Dixson, M. Gagliano, and H.Y. Yan, Ocean acidification erodes crucial auditory behaviour in a marine fish, Biol. Lett. 7 (2011) 917-920.

[74] D.L. Dixson, A.R. Jennings, J. Atema, and P.L. Munday, Odor tracking in sharks is reduced under future ocean acidification conditions, Glob. Change Biol. doi: 10.1111/gcb.12678 (2014).

[75] G.M. Miller, S.-A. Watson, M.I. McCormick, and P.L. Munday, Increased $\mathrm{CO}_{2}$ stimulates reproduction in a coral reef fish, Glob. Change Biol. 19 (2013) 3037-3045.

[76] H.O. Pörtner, and A.P. Farrell, Physiology and climate change, Science 322 (2008) 690692.

[77] H. Baumann, S.C. Talmage, and C.J. Gobler, Reduced early life growth and survival in a fish in direct response to increased carbon dioxide, Nature Climate Change 2 (2012) 38-41. 
[78] D. Bromhead, V. Scholey, S. Nicol, D. Margulies, J. Wexler, M. Stein, S. Hoyle, C. Lennert-Cody, J. Williamson, J. Havenhand, T. Ilyina, and P. Lehodey, The potential impact of ocean acidification upon eggs and larvae of yellowfin tuna (Thunnus albacares), Deep Sea Research II 113 (2015) 268-279.

[79] D.M. Checkley Jr., A.G. Dickson, M. Takahashi, J.A. Radich, N. Eisenkolb, and R. Asch, Elevated $\mathrm{CO}_{2}$ enhances otolith growth in young fish, Science 324 (2009) 1683.

[80] P.L. Munday, M. Gagliano, J.M. Donelson, D.L. Dixson, and S.R. Thorrold, Ocean acidification does not affect the early life history development of a tropical marine fish, Mar. Ecol. Prog. Ser. 423 (2011) 211-221.

[81] P.L. Munday, V. Hernman, D.L. Dixson, and S.R. Thorrold, Effect of ocean acidification on otolith development in larvae of a tropical marine fish, Biogeosciences 8 (2011) 16311641.

[82] A. Franke, and C. Clemmesen, Effect of ocean acidification on early life stages of Atlantic herring (Clupeaharengus L.), Biogeosciences 8 (2011) 3697-3707.

[83] E.C. Pope, R.P. Ellis, M. Scolamacchia, J.W.S. Scolding, A. Keay, P. Chingombe, R.J. Shields, R. Wilcox, D.C. Speirs, R.W. Wilson, C. Lewis, and K.J. Flynn, European sea bass, Dicentrarchuslabrax, in a changing ocean, Biogeosciences 11 (2014) 2519-2530.

[84] B. Michaelidis, A. Spring, and H.O. Pörtner, Effects of long-term acclimation to environmental hypercapnia on extracellular acid-base status and metabolic capacity in Mediterranean fish Sparusaurata, Mar. Biol. 150 (2007) 1417-1429.

[85] E. Réveillac, T. Lacoue-Labarthe, F. Oberhänsli, J.-L. Teyssié, R. Jeffree, J.-P. Gattuso, and S. Martin, Ocean acidification reshapes the otolith-body allometry of growth in juvenile seabream, J. Exp. Mar. Biol. Ecol. 463 (2015) 87-94.

[86] P. Martín, A. Sadatés, J. Lloret, and J. Martin-Vide, Climate modulation of fish populations: the role of the Western Mediterranean Oscillation (WeMO) in sardine (Sardina pilchardus) and anchovy (Engraulis encrasicolus) production in the north-western Mediterranean, Clim. Change 110 (2012) 925-939.

[87] L.C. Rodrigues, J.C.M. ven der Bergh, and A. Ghermandi, Socio-economic impacts of ocean acidification in the Mediterranean Sea, Marine Policy 38 (2013) 447-456.

[88] I.H. Langford, A. Kontogianni, M.S. Skourtos, S. Georgiou, and I.J. Bateman, Multivariate mixed models for open-ended contingent valuation data: willingness to pay for conservation of monk seals, Environ. Resources Econom. 12 (1998) 443-456.

[89] P.A.L.D. Nunes, and J.C.J.M.v.d. Bergh, Economic valuation of biodiversity: sense or nonsense?, Ecol. Econ. 39 (2001) 203-222.

[90] K. Remoundou, P. Koundouri, A. Kontogianni, P.A.L.D. Nunes, and M. Skourtos, Valuation of natural marine ecosystems: an economic perspective, Environ. Sci. Policy 12 (2009) 1040-1051.

[91] A. Israel, and M. Hophy, Growth, photosynthetic properties and Rubisco actvities and amounts of marine macroalgae grown under current and elevated seawater $\mathrm{CO}_{2}$ concentrations, Glob. Change Biol. 8 (2002) 831-840.

[92] O. Invers, J. Romero, and M. Pérez, Effects of $\mathrm{pH}$ on seagrass photosynthesis: a laboratory and field assessment, Aquat. Bot. 59 (1997) 185-194.

[93] J. Hall-Spencer, R. Rodolfo-Metalpa, S. Martin, E. Ransome, M. Fine, S.M. Turner, S.J. Rowley, D. Tedesco, and M.-C. Buia, Volcanic carbon dioxide vents show ecosystem effects of ocean acidification, Nature 454 (2008) 96-99.

[94] V.R. Johnson, B.D. Russell, K.E. Fabricius, C. Brownlee, and J. Hall-Spencer, Temperate and tropical brown macroalgae thrive, despite decalcification, along natural $\mathrm{CO}_{2}$ gradients, Glob. Change Biol. 18 (2012) 2792-2803.

[95] L. Porzio, M.C. Buia, and J.M. Hall-Spencer, Effects of ocean acidification on macroalgal communities, J. Exp. Mar. Biol. Ecol. 400 (2011). 
[96] S. Martin, S. Cohu, C. Vignot, G. Zimmerman, and J.-P. Gattuso, One-year experiment on the physiological response of the Mediterranean crustose coralline alga, Lithophyllumcabiochae, to elevated pCO2 and temperature, Ecology and Evolution 3 (2013) 676-693.

[97] K.J. Kroeker, F. Micheli, and M.C. Gambi, Ocean acidification causes ecosystem shifts via altered competitive interactions, Nature Climate Change 3 (2013) 156-159.

[98] M. Milazzo, R. Rodolfo-Metalpa, V.B.S. Chan, M. Fine, C. Alessi, V. Thiyagarajan, J.M. Hall-Spencer, and R. Chemello, Ocean acidification impairs vermetid reef recruitment, Scientific Reports 4 (2014) 4189.

[99] N. Hilmi, D. Allemand, S. Dupont, A. Safa, G. Haraldsson, P.A.L.D. Nunes, C. Moore, C. Hattam, S. Reynaud, J.M. Hall-Spencer, M. Fine, C. Turley, R. Jeffree, J. Orr, P.L. Munday, and S.R. Cooley, Towards improved socio-economic assessments of ocean acidification's impacts, Mar. Biol. 160 (2012) 1773-1787.

[100] L. Bramanti, J. Movilla, M. Guron, E. Calvo, A. Gori, C. Dominguez-Carrio, J. Griny, A. Lopéz-Sanz, A. Martinez-Quintana, C. Pelejero, P. Ziveri, and S. Rossi, Detrimental effects of ocean acidification on the economically important Mediterranean red coral (Coralliumrubrum), Glob. Change Biol. 19 (2013) 1897-1908.

[101] C. Maier, A. Schubert, M.M.B. Sànchez, M.G. Weinbauer, P. Watremez, and J.-P. Gattuso, End of the century $p \mathrm{CO} 2$ levels do not impact calcification in mediterranean coldwater corals, PLoS ONE 8 (2013) e62655.

[102] J. Movilla, A. Gori, E. Calvo, C. Orejas, À. López-Sanz, C. Domínguez-Carrió, J. Grinyó, and C. Pelejero, Resistance of two mediterranean cold-water coral species to low-pH conditions, Water 6 (2014) 59-67.

[103] T.E. Cox, S. Schenone, J. Delille, V. Dìaz-Castañeda, S. Alliouane, J.P. Gattuso, and F. Gazeau, Effects of ocean acidification on Posidoniaoceanica epiphytic community and shoot productivity, J. Ecol. doi: 10.1111/1365-2745.12477 (in press).

[104] U. Riebesell, J.-P. Gattuso, T.F. Thingstad, and J.J. Middelburg, Arctic ocean acidification: pelagic ecosystem and biogeochemical responses during a mesocosm study, Biogeosciences 10 (2013) 5619-5626.

[105] L. Maugendre, J.-P. Gattuso, J. Louis, A.d. Kluijver, S. Marro, K. Soetaert, and F. Gazeau, Effect of ocean warming and acidification on a plankton community in the NW Mediterranean Sea, ICES J. Mar. Sci. 72 (2015) 1744-1755.

[106] P. Ziveri, M. Passaro, A. Incarbona, M. Milazzo, R. Rodolfo-Metalpa, and J. HallSpencer, Decline in coccolithophore diversity and impact on coccolith morphogenesis along a natural $\mathrm{CO}_{2}$ gradient, Biol. Bull. 226 (2014) 282-290.

[107] L. Maugendre, J.-P. Gattuso, A.J. Poulton, W. Dellisanti, M. Gaubert, C. Guieu, and F. Gazeau, No detectable effect of ocean acidification on plankton metabolism in the NW oligotrophic Mediterranean Sea: Results from two mesocosm studies, Estuarine, Coastal and Shelf Science (in press) doi.org/10.1016/j.ecss.2015.1003.1009.

[108] S. Comeau, G. Gorsky, S. Alliouane, and J.-P. Gattuso, Larvae of the pteropod Cavoliniainflexa exposed to aragonite undersaturation are viable but shell-less, Mar. Biol. 157 (2010) 2341-2345.

[109] S. Zervoudaki, C. Frangoulis, L. Giannoudi, and E. Krasakopoulou, Effects of low pH and raised temperature on egg production, hatching and metabolic rates of a Mediterranean copepod species (Acartiaclausi) under oligotrophic conditions, Mediterranean Marine Science 15 (2013) 74-83.

[110] K.J. Kroeker, F. Micheli, M.C. Gambi, and T.R. Martz, Divergent ecosystem responses within a benthic marine community to ocean acidification, Proc. Natl. Acad. Sci. U. S. A. 108 (2011) 14515-14520. 
[111] D.J. Suggett, J.M. Hall-Spencer, R. Rodolfo-Metalpa, T.G. Boatman, R. Payton, D.T. Pettay, V.R. Johnson, M.E. Warner, and T. Lawson, Sea anemones may thrive in a high $\mathrm{CO}_{2}$ world, Glob. Change Biol. 18 (2012) 3015 - 3025.

[112] A.K. Winans, and J.E. Purcell, Effects of $\mathrm{pH}$ on asexual reproduction and statolith formation of the scyphozoan, Aurelia labiata, Hydrobiologia 645 (2010) 39-52.

[113] D. Kerfahi, J.M. Hall-Spencer, B.M. Tripathi, M. Milazzo, J. Lee, and J.M. Adams, Shallow water marine sediment bacterial community shifts along a natural $\mathrm{CO}_{2}$ gradient in the Mediterranean Sea off Vulcano, Italy, Microb. Ecol. 67 (2014) 819-828.

[114] J.M. Hall-Spencer, and R. Allen, The impact of ocean acidification on 'nuisance' species, Research and Reports in Biodiversity Studies 4 (2015) 33-46.

[115] R. Rosa, A. Marques, and M.L. Nunes, Impact of climate change in Mediterranean aquaculture, Reviews in Aquaculture 4 (2012) 163-177.

[116] D.L. Erdner, J. Dyble, M.L. Parsons, R.C. Stevens, K.A. Hubbard, M.L. Wrabel, S.K. Moore, K.A. Lefebvre, D.M. Anderson, P. Bienfang, R.R. Bidigare, M.S. Parker, P. Moeller, L.E. Brand, and V.L. Trainer, Centers for Oceans and Human Health: a unified approach to the challenge of harmful algal blooms, Environmental Health 7 (2008) S1.

[117] M.-L. Chateau-Degat, M. Chinain, N. Cerf, S. Gingras, B. Hubert, and â. Dewailly, Seawater temperature, Gambierdiscus spp. variability and incidence of ciguatera poisoning in French Polynesia, Harmful Algae 4 (2005) 1053-1062.

[118] S.K. Moore, N.J. Mantua, B.M. Hickey, and V.L. Trainer, The relative influences of El Nino-Southern Oscillation and Pacific Decadal Oscillation on paralytic shellfish toxin accumulation in Pacific northwest shellfish, Limnol. Oceanogr. 55 (2010) 2262-2274.

[119] L. Mangialajo, R. Bertolotto, R. Cattaneo-Vietti, M. Chiantore, C. Grillo, R. Lemee, N. Melchiorre, P. Moretto, P. Povero, and N. Ruggieri, The toxic benthic dinoflagellate Ostreopsis ovata: Quantification of proliferation along the coastline of Genoa, Italy, Mar. Pollut. Bull. 56 (2008) 1209-1214.

[120] F.X. Fu, A.R. Place, N.S. Garcia, and D.A. Hutchins, $\mathrm{CO}_{2}$ and phosphate availability control the toxicity of the harmful bloom dinoflagellate Karlodiniumveneficum, Aquat. Microb. Ecol. 59 (2010) 55-65.

[121] A.O. Tatters, F.-X. Fu, and D.A. Hutchins, High $\mathrm{CO}_{2}$ and silicate limitation synergistically increase the toxicity of Pseudo-nitzschiafraudulenta, PLoS ONE 7 (2012) e32116.

[122] F.J. Millero, R. Woosley, B. Ditrolo, and J. Waters, Effect of ocean acidification on the speciation of metals in seawater, Oceanography 22 (2009) 72-85.

[123] T. Lacoue-Labarthe, S. Martin, F. Oberhänsli, J.-L. Teyssié, R. Jeffree, J.-P. Gattuso, and P. Bustamante, Temperature and $p \mathrm{CO}_{2}$ effect on the bioaccumulation of radionuclides and trace elements in the eggs of the common cuttlefish Sepia officinalis J. Exp. Mar. Biol. Ecol. 413 (2012) 45-49.

[124] T. Lacoue-Labarthe, E. Réveillac, F. Oberhänsli, J.-L. Teyssié, R. Jeffree, and J.-P. Gattuso, Effects of ocean acidification on trace element accumulation in the early-life stages of squid Loligo vulgaris, Aquat. Toxicol. 105 (2011) 166-176.

[125] I.R. López, J. Kalman, C. Vale, and J. Blasco, Influence of sediment acidification on the bioaccumulation of metals in Ruditapes philippinarum, Environ. Sci. Pollut. Res. 17 (2010) 1519-1528.

[126] A.V. Ivanina, E. Beniash, M. Etzkorn, T.B. Meyers, A.H. Ringwood, and I.M. Sokolova, Short-term acute hypercapnia affects cellular responses to trace metals in the hard clams Mercenariamercenaria, Aquat. Toxicol. 140-141 (2013) 123-133.

[127] T. Lacoue-Labarthe, S. Martin, F. Oberhänsli, J.L. Teyssie, S.J. Markich, R. Jeffree, and P. Bustamante, Effects of increased $p \mathrm{CO}_{2}$ and temperature on trace element $(\mathrm{Ag}, \mathrm{Cd}$ and 
$\mathrm{Zn}$ ) bioaccumulation in the eggs of the common cuttlefish, Sepia officinalis, Biogeosciences 6 (2009) 2561-2573.

[128] W.G. Wallace, and S.N. Luoma, Subcellular compartmentalization of Cd and $\mathrm{Zn}$ in two bivalves. II. Significance of trophically available metal (TAM), Mar. Ecol. Prog. Ser. 257 (2003) 125-137.

[129] A. Viarengo, and J.A. Nott, Mechanisms of heavy metal cation homeostasis in marine invertebrates, Comp. Biochem. Physiol. 104C (1993) 355-372.

[130] Millennium Ecosystem Assessment, Ecosystems and Human Well-Being: Policy Responses, Island Press, Washington DC, 2005.

[131] R Core Team, R: A language and environment for statistical computing, R Foundation for Statistical Computing, Vienna, Austria, http://www.R-project.org/

[132] E. Pante, and B. Simon-Bouhet, Marmap: a package for importing, plotting and analyzing bathymetric and topographic data in R, PLoS ONE 8 (2013) e73051.

[133] J. Lemon, Plotrix: a package in the red light district of R, R-News 6 (2006) 8-12. 


\section{Figures Captions}

Figure 1. Mediterranean Sea and bordering countries.

Figure 2. Trends of capture fisheries and aquaculture production in countries of the General Fisheries Commission for the Mediterranean (GFCM) from 1991 to 2010. Data source: (*) FAO Capture Production in GFCM statistical area (release data: February 2012) - (**) Production in GFCM countries (aquaculture from Atlantic areas excluded) - SIPAM-FAO Aquaculture Production 19592010 (Released date: March 2012).

Figure 3. Capture production of the Mediterranean Sea fisheries in 2011. Data extracted from "GFCM Capture Production" databases from FAO.

Figure 4. Trends of landings (in tonnes) of sardine (Sardinapilchardus), anchovy (Engraulisencrasicolus), sardinella (Sardinellaaurita) and other small pelagic fish in Mediterranean Sea from 1970 to 2011. Data extracted from "GFCM Capture Production" databases from FAO.

Figure 5: Bivalve production from aquaculture in Mediterranean Sea. Data extracted from "Global aquaculture production" databases from FAO.

Figure 6. Spatial distribution of seasonal $\mathrm{pH}$ ranges driven by physical processes only (from the highresolution CMCC model). 


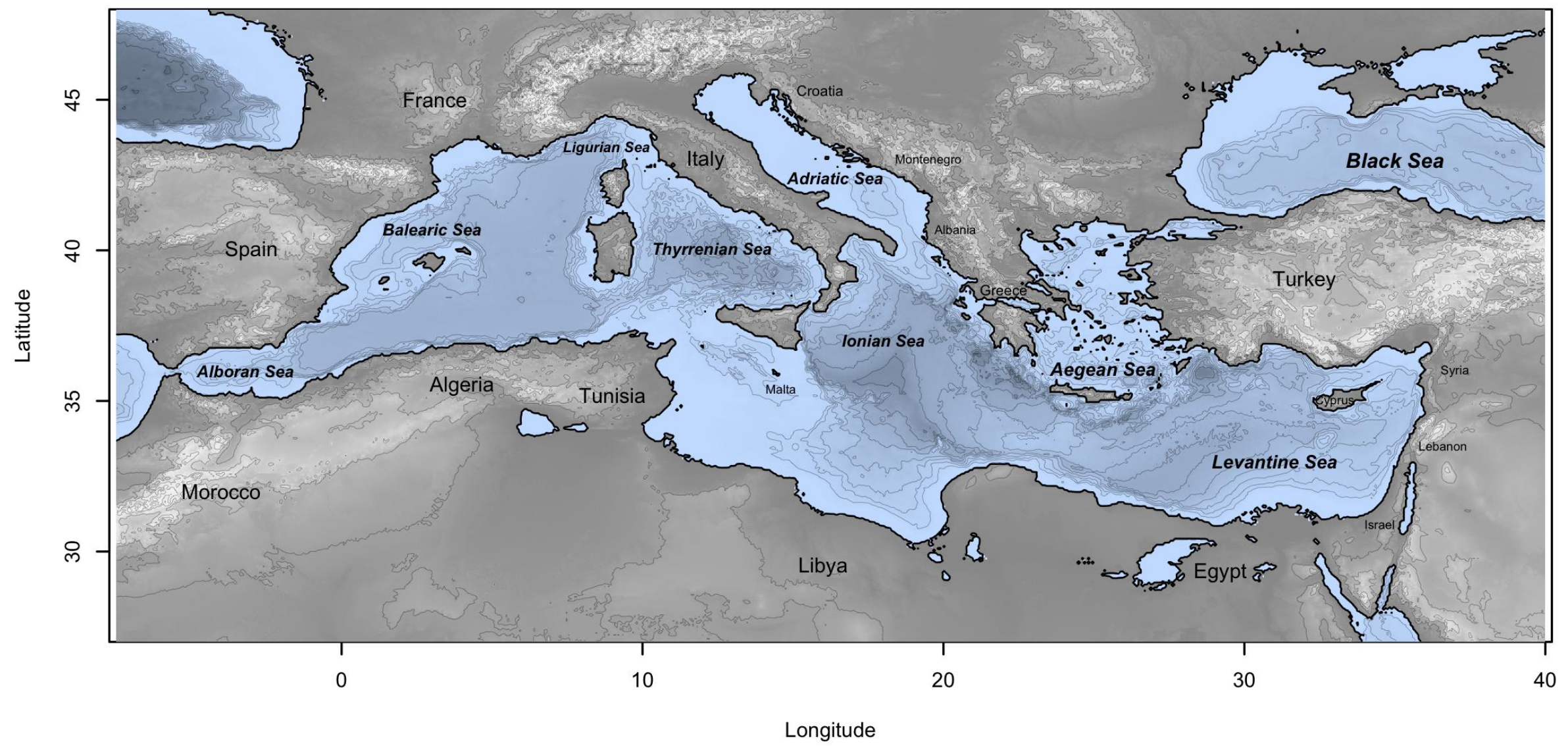

Figure 1 


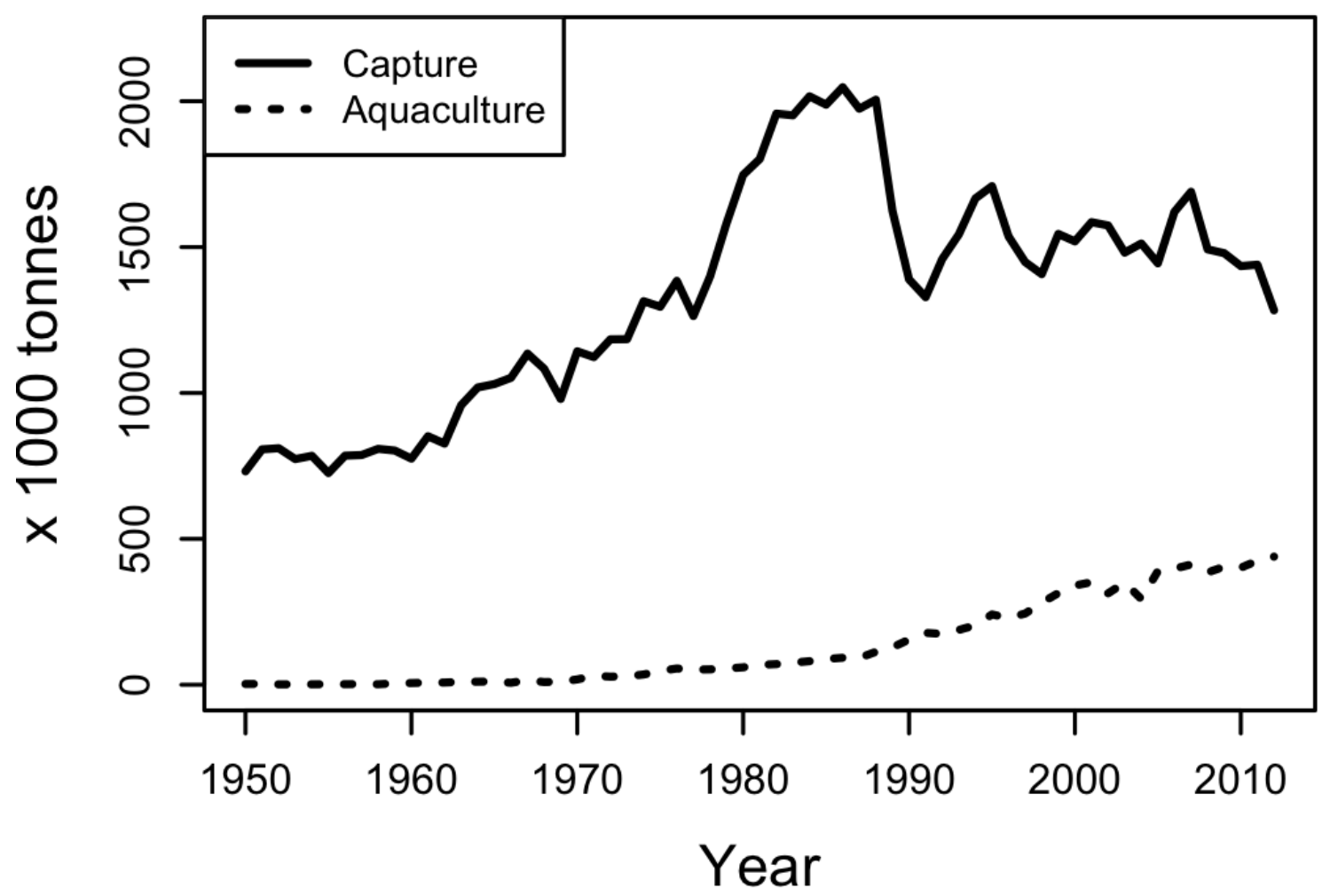




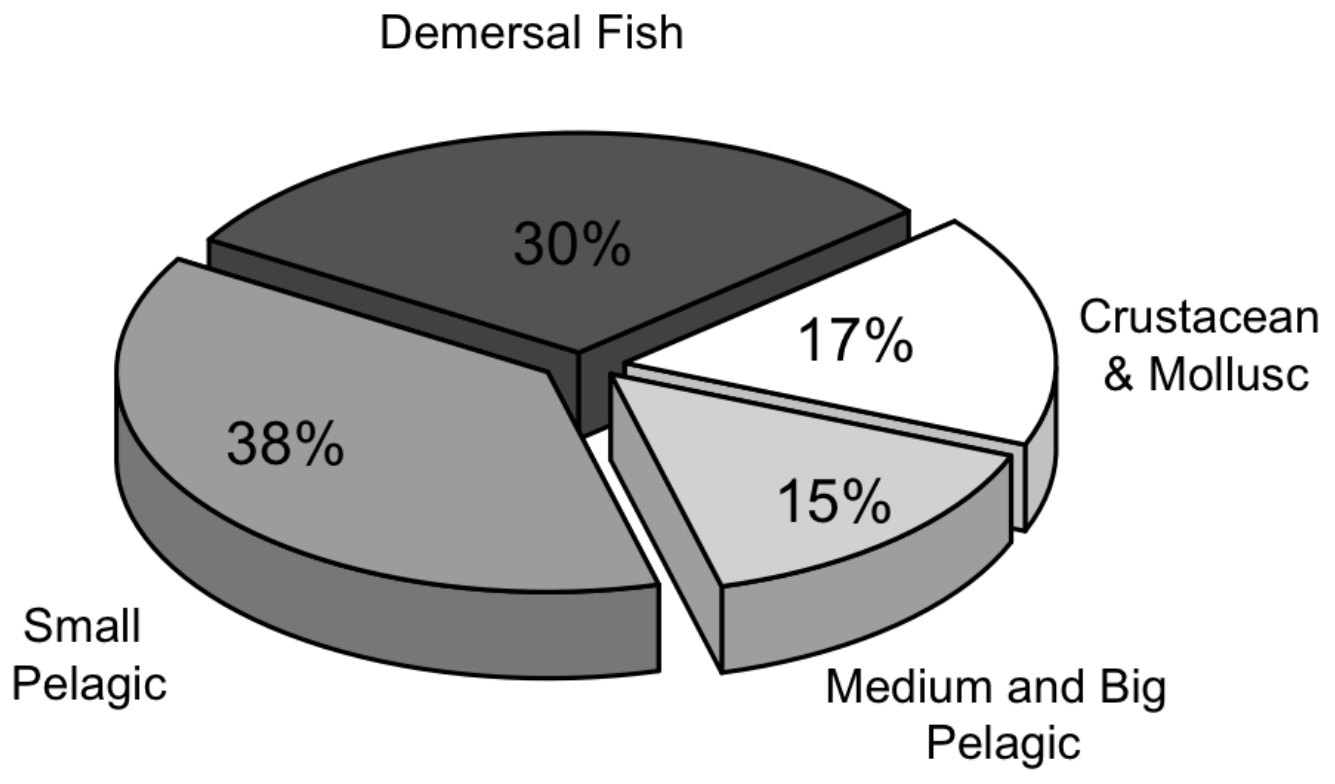

Figure 3 


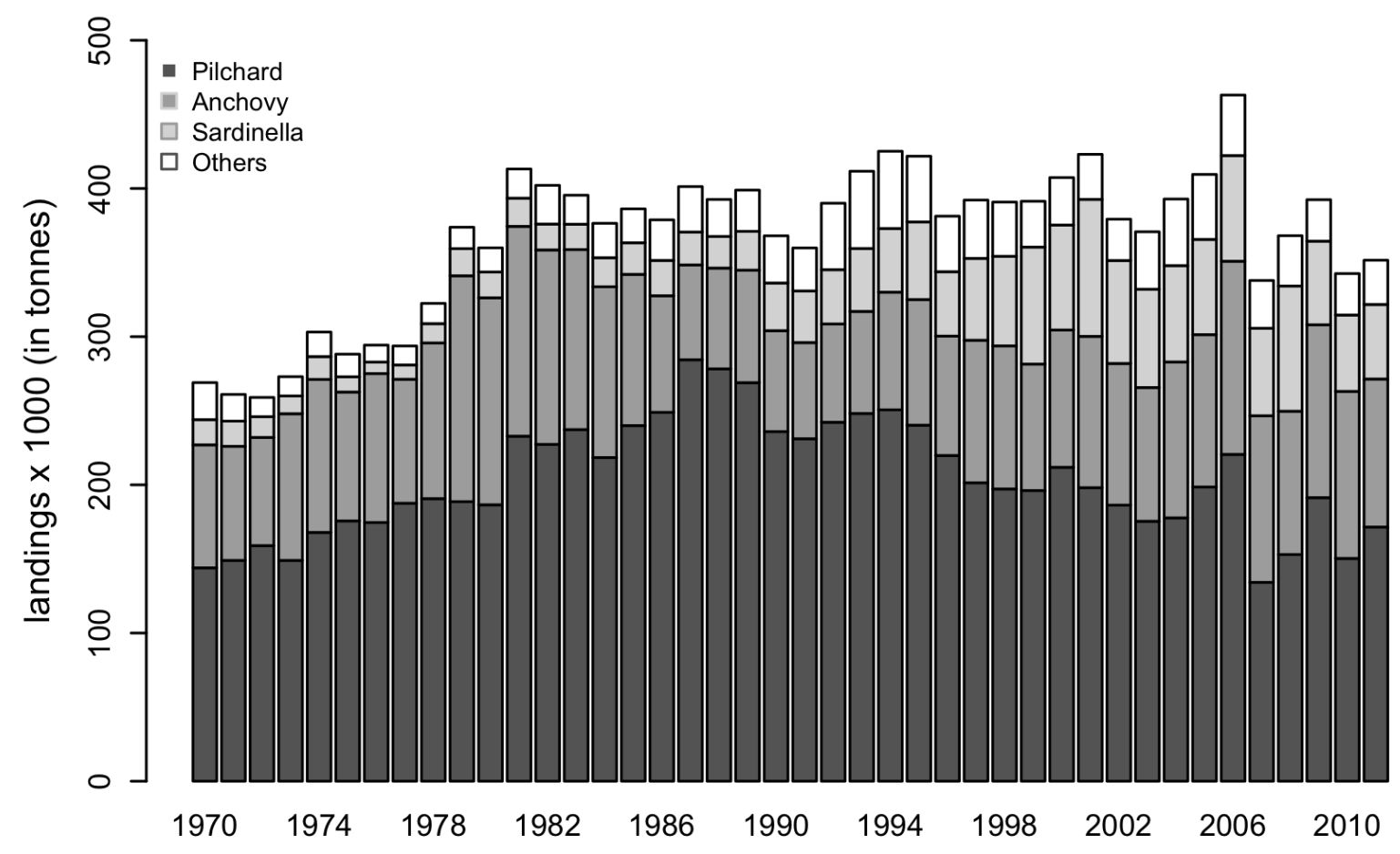

Figure 4 

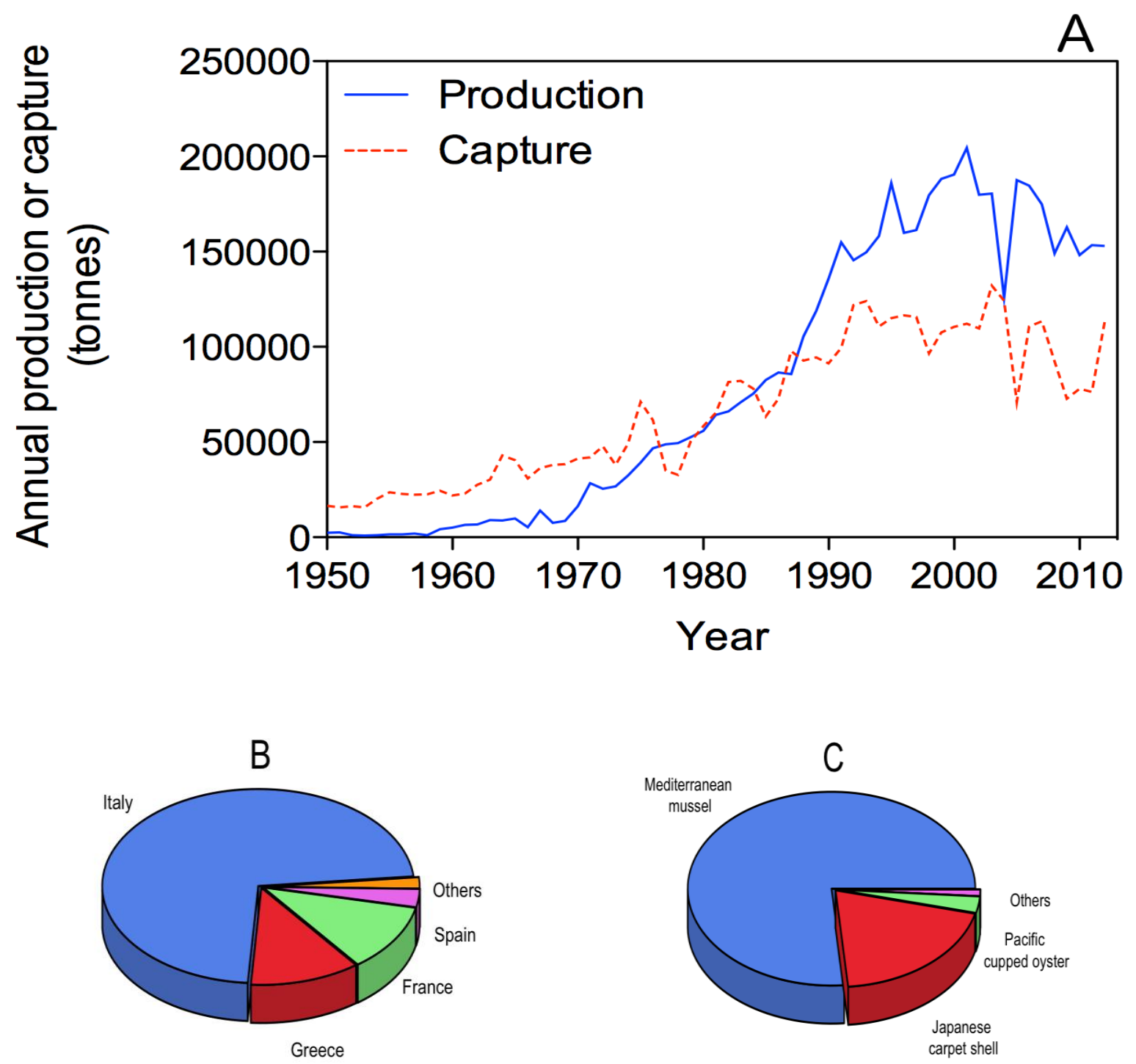

Figure 5 


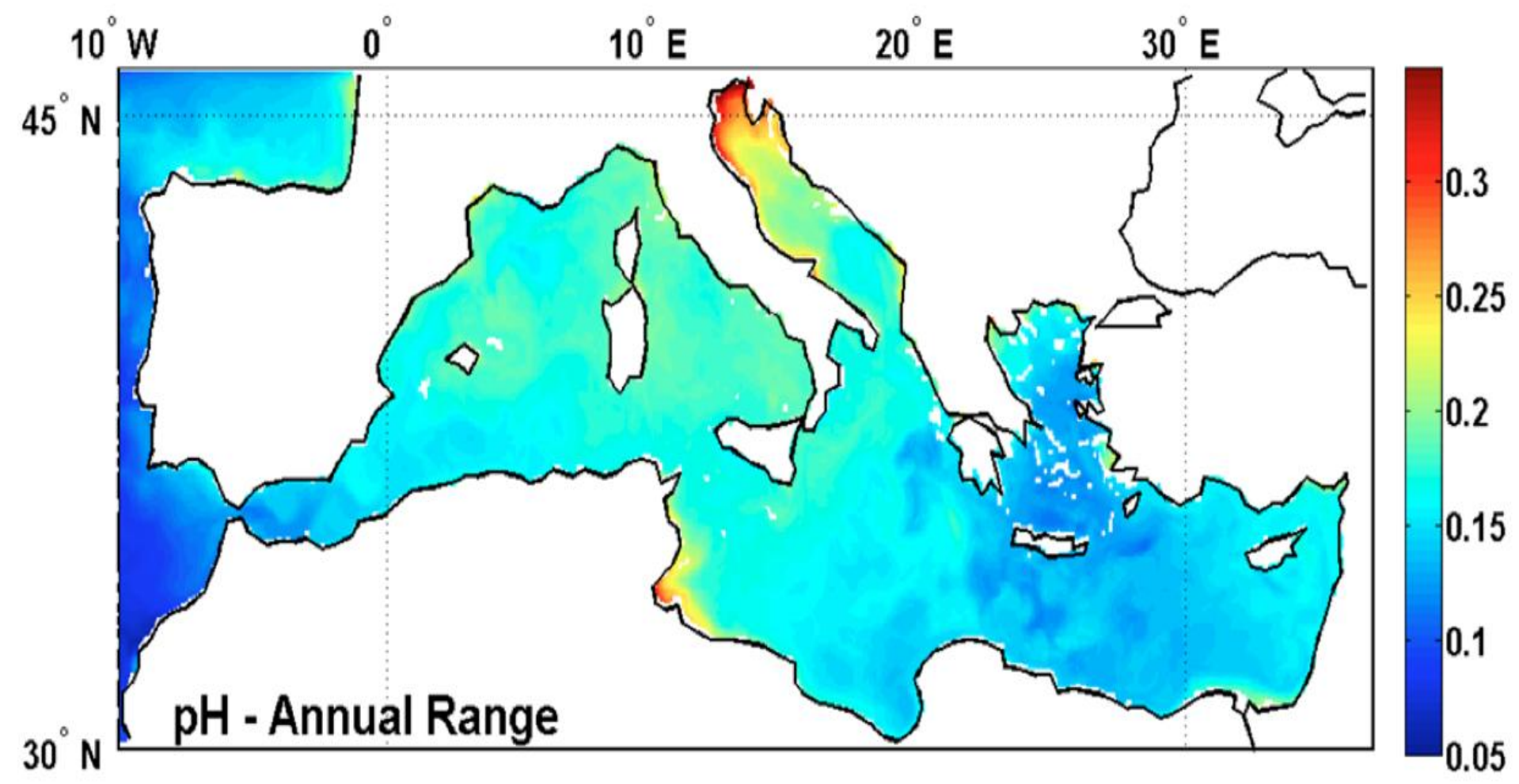

Figure 6 